\title{
RESENSI \\ Advances in Biomaterials Science and Biomedical Applications
}

\author{
Joko Triyono \\ Program Studi Teknik Mesin \\ Universitas Negeri Sebelas Maret
}

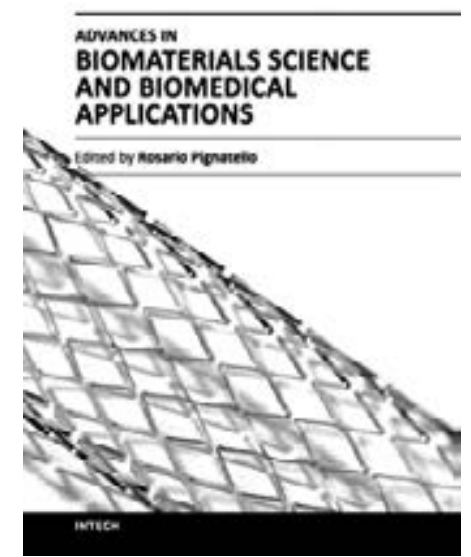

Editor

Penerbit

Cetakan

Tebal

ISBN

"Advances in Biomaterials Science and Biomedical Applications" merupakan buku teks yang disusun oleh beberapa penulis dari berbagai disiplin ilmu dari berbagai negara. Setiap bab yang ditulis merupakan hasil kajian, penelitian atau pengalaman pribadi penulis. Para pembaca dapat memperoleh gambaran umum untuk mengetahui potensi biomaterial di masa-masa mendatang. Pembaca juga akan mendapatkan gambaran bagaimana proses fabrikasi

material implan berbasis organ manusia dilakukan dengan teknologi cetak 3 dimensi (3D printing). Buku ini terbagi menjadi 21 bab. Setiap bab diulas secara detail agar mudah dipahami.

Bab I tentang "Biomedical Applications of Materials Processed in Glow Discharge Plasma"disusun oleh V. Tereshko, A. Gorchakov, I. Tereshko, V. Abidzina and V. Red'ko. Pada Bab ini dijelaskan tentang aplikasi material biomedis yang diproses dengan teknologi Glow Discharge Plasma (GDP). Dengan teknologi ini modifikasi material bulk dalam debit plasma dapat dilakukan. Teknologi ini sangat efisien untuk material logam dan paduan yang memiliki energi ion rendah (sampai $5 \mathrm{keV}$ ).

Bab II tentang "Mechanical Properties of Biomaterials Based on Calcium Phosphates and Bioinert Oxides for Applications in Biomedicine" disusun oleh Siwar Sakka, Jamel Bouaziz and Foued Ben Ayed. Pada bab ini dipaparkan beberapa jenis biomaterial kalsium fosfat seperti hidroksiapatit $\left(\mathrm{Ca}_{10}\left(\mathrm{PO}_{4}\right)_{6}(\mathrm{OH})_{2^{\prime}}\right.$ $\mathrm{HAp})$, fluorapatit $\left(\mathrm{Ca}_{10}\left(\mathrm{PO}_{4}\right) 6 \mathrm{~F}_{2}, \mathrm{FAp}\right)$, trikalsium fosfat $\left(\mathrm{Ca}_{3}\left(\mathrm{PO}_{4}\right)_{2}, \mathrm{TCP}\right)$, komposit TCP-
HAp dan komposit TCP-FAp yang digunakan untuk aplikasi medis dan gigi. Daftar lengkap kalsium fosfat yang dikenal termasuk sifat utama mereka (seperti formula kimia, data kelarutan) disajikan dalam bentuk tabel.

Bab III tentang "Degradation of Polyurethanes for Cardiovascular Applications" disusun oleh Juan V. Cauich-Rodríguez, Lerma $H$. Chan-Chan, Fernando Hernandez-Sánchez and José M. CervantesUc. Pada Bab ini dijelaskan penggunaan poliuretan untuk aplikasi biomedis di bidang kardiovaskular. Penggunaan polimer ini berkaitan dengan sifat fisikokimia, mekanik, dan biokompatibilitas yang baik. Poliuretan tersegmentasi (SPUs) telah digunakan dalam aplikasi kardiovaskular sebagai perangkat permanen seperti pacu jantung dan perangkat bantu ventrikel, tetapi fleksibilitas chemistry yang sangat baik, SPUs juga dapat disesuaikan untuk membuat sistem biodegradable untuk rekayasa jaringan cangkokan pembuluh darah dan katup jantung. Banyak penelitian telah difokuskan pada berbagai komposisi kimia untuk meningkatkan biostabilitas untuk mengendalikan biodegradabilitas poliuretan 
tergantung pada aplikasi spesifik di bidang kardiovaskular. Dalam bab ini, aspek umum dari kimia poliuretan disajikan terlebih dahulu kemudian berbagai jenis sifat degradasi yang dapat mempengaruhi polimer ini dijelaskan baik secara in vivo maupun in vitro.

Bab IV tentang "Substrates with Changing Properties for Extracellular Matrix Mimicry" disusun oleh Frank Xue Jiang. Pada Bab ini dijelaskan tentang interaksi sel-ECM (Extra Cellular Matrix) sebagai dasar keberhasilan penggunaan biomaterial dalam aplikasi perawatan kesehatan dan medis. Tiga fitur utama ECM telah diidentifikasi sangat penting dalam mempengaruhi sel, yaitu komposisi kimia dan biologi, dimensi (dua-tiga dimensi), dan sifat fisik. Fitur-fitur ini dapat dirasakan oleh sel melalui hubungan sel-ECM, dan sinyal yang dihasilkan kemudian mengikuti jalur intraselular dan memicu serangkaian kejadian yang menyebabkan perubahan ekspresi gen dan manifestasi pada fenotipe.

Bab V tentang "Overview on Biocompatibilities of Implantable Biomaterials"disusun oleh Xiaohong Wang. Pada bab ini dijelaskan tentang sifat-sifat biokompatibilitas material implan yang selama satu dekade terakhir digunakan di dunia medis. Biomaterial yang disajikan yakni implan sederhana seperti lensa intraokular (yang mengembalikan penglihatan kepada jutaan pasien katarak setiap tahun), jahitan, pembalut luka, matriks dekelular, lempeng tulang, penggantian sendi dengan bahan yang lebih kompleks seperti biosensor, kateter, Alat pacu jantung, pembuluh darah, jantung buatan.

Bab VI tentang In vitro Blood Compatibility of Novel Hydrophilic Chitosan Films for Vessel Regeneration and Repair disusun oleh Antonello A. Romani, Luigi Ippolito, Federica Riccardi, Silvia Pipitone, Marina Morganti, Maria Cristina Baroni, Angelo F. Borghetti and Ruggero Bettini. Pada bab ini dijelaskan sifat biokompatibilitas in vitro terhadap lapisan tipis chitosan pada proses regenerasi dan perbaikan pembuluh darah. $\mathrm{Bab}$ ini juga menjelaskan bagaimana solusi aktual untuk mengatasi kegagalan organ setelah mengalami penolakan kekebalan.
BabVII tentang Amelioration of Blood Compatibility and Endothelialization of Polycaprolactone Substrates by SurfaceInitiated Atom Transfer Radical Polymerization disusun oleh Shaojun Yuan, Gordon Xiong, Ariel Roguin, Swee Hin Teoh, dan Cleo Choong. Pada bab ini dijelaskan tentang berbagai strategi yang dikembangkan untuk memperbaiki kompatibilitas permukaan biomaterial darah, termasuk imobilisasi permukaan anti-koagulan seperti heparin dan serat sutra sulfat, penggabungan polyethylene oxide atau rantai samping bermuatan negatif dan passivasi permukaan dengan lapisan protein, seperti albumin. Hal ini dilatarbelakangi karena sulitnya penggantuan graft berdiameter kecil ( $<6 \mathrm{~mm})$.

Bab VIII tentang Cell Adhesion to Biomaterials: Concept of Biocompatibility disusun oleh M. Lotfi, M. Nejib and M. Naceur. Pada bab ini dijelaskan definisi adhesi sel dan manfaatnya. Dijelaskan juga dalam bab ini adalah arti pentingnya membran sel dalam kaitannya dengan adhesi sel. Bab IX tentang Nanoparticles Based on Chitosan Derivatives disusun oleh Ylenia Zambito. Bab ini dijelaskan pemanfaatan turunan chitosan sebagai nanomaterial $(<1 \mu \mathrm{m})$ di bidang kedokteran dan farmasi. Chitosan, sebuah kopolimer glucosamine dan $\mathrm{N}$-acetylglucosamine, diperoleh dengan deasetilasi dari chitin yang terjadi secara alami. Chitosan dipilih karena bersifat biodegradable dan memiliki toksisitas yang sangat rendah.

Bab X tentang $p H$-Sensitive Nanocrystals of Carbonate A patite: a Powerful and Versatile Tool for Efficient Delivery of Genetic Materials to Mammalian Cells disusun oleh Ezharul Hoque Chowdhury Pada bab ini dijelaskan manfaat pengiriman DNA ke sel mamalia dan manfaat terapi gen untuk mengobati penyakit manusia yang kritis. Pada bab ini dijelaskan juga keterbatasan utama pengiriman DNA ke sel mamalia seperti toksisitas, imunogenisitas, keterbatasan jenis sel tertentu, keterbatasan kapasitas pembawa DNA, masalah produksi dan pengemasan serta rekombinasi dan tinggi biaya'. 
Bab XI Innovative Strategies for Tissue Engineering disusun oleh Juliana Lott Carvalho, Pablo Herthel de Carvalho, Dawidson Assis Gomes and Alfredo Miranda de Goes. Pada bab ini dijelaskan inovasiinovasi yang telah dilakukan para peneliti dalam hal rekayasa jaringan tubuh. Inovasi ini berkembang sejalan dengan semakin meningkatnya populasi penduduk di dunia. Dengan semakin banyak penduduk akan semakin banyak pula tantangan kehidupan: kecelakaan, malformasi, kecelakaan, infeksi kronis, penyakit degenerative, dan kegagalan organ.

Bab XII tentang Biofabrication of Tissue Scaffolds disusun oleh Ning Zhu and Xiongbiao Chen. Pada bab ini dijelaskan tentang proses fabrikasi jaringan tiruan berbasis organ pasien. Teknologi yang dikembangkan antara lain seperti electrospinning, teknik fabrikasi berbasis nanoteknologi, dan teknologi 3D-printing. Bab XIII tentang Biomaterials and Stem Cell Therapies for Injuries Associated to Skeletal Muscular Tissues disusun oleh Tiago Pereira, Andrea Gärtner, Irina Amorim, Paulo Armada-da-Silva, Raquel Gomes' Cátia Pereira, Miguel L. França, Diana M. Morais, Miguel A. Rodrigues, Maria A. Lopes, José D. Santos, Ana Lúcia Luís and Ana Colette Maurício. Pada bab ini dijelaskan tentang manfaat biomaterial dan terapi sel induk untuk cedera otot. Bab ini juga memaparkan beberapa faktor keberhasilan pengobatan dengan sel induk, antara lain: sel induk dapat tumbuh dan terbagi tanpa batas waktu, sel induk dapat berdiferensiasi menjadi tipe sel khusus, seperti otot skeletal dan sel induk dapat dikirim ke tempat lesi yang terkait dengan biomaterial.

Bab XIV Alignment of Cells and Extracellular Matrix Within Tissue-Engineered Substitutes disusun oleh Jean-Michel Bourget, Maxime Guillemette, Teodor Veres, François A. Auger dan Lucie Germain. Pada bab ini dijelaskan fungsi sel dan komponen matriks ekstraselular (ECM) dalam tubuh. Di bidang pengembangan teknik jaringan tubuh, agar mereka dapat berfungsi dengan baik, perlu dipertimbangkan komposisi scaffold (sintetis, alami, sifat biodegradable), organisasi dan dimensi strukturnya. Bab XV Autograft of Dentin Materials for Bone Regeneration disusun oleh Masaru Murata, Toshiyuki Akazawa, Masaharu Mitsugi, Md Arafat Kabir, InWoong Um, Yasuhito Minamida, KyungWook Kim, Young-Kyun Kim, Yao Sun dan Chunlin Qin. Pada bab ini dijelaskan tentang pengembangan bahan dentin bioabsorbable yang diselaraskan dengan remodeling tulang, dengan menggunakan teknologi supersonik dan asam-etsa. Dentin adalah matriks aselular, sedangkan tulang termasuk osteosit. Yang sangat menarik, komponen biokimia dalam dentin dan tulang hampir mirip.

Bab XVI Healing Mechanism and Clinical Application of Autogenous Tooth Bone Graft Material disusun oleh Young-Kyun Kim, Jeong Keun Lee, Kyung-Wook Kim, InWoong Um and Masaru Murata. Pada bab ini dijelaskan jenis-jenis material cangkok gigi yakni autogenous bone, allogenic bone, xenogenic bone, dan alloplastic. Tulang autogenous adalah yang paling ideal karena mampu osteogenesis, osteoinduksi, dan osteokonduksi. Keuntungannya adalah waktu penyembuhan yang cepat tanpa penolakan kekebalan tubuh. Kekurangan terbesarnya adalah persediaan yang terbatas. Pada bab ini juga dijelaskan penggunaan dentin manusia dari gigi yang diekstraksi untuk cangkokan tulang autogenous. Bab XVII The Integrations of Biomaterials and Rapid Prototyping Techniques for Intelligent Manufacturing of Complex Organs disusun oleh Xiaohong Wang, Jukka Tuomi, Antti A. Mäkitie, Kaija-Stiina Paloheimo, Jouni Partanen dan Marjo Yliperttula. Pada bab ini dijelaskan tentang kolaborasi antara bagian biomaterial dengan proses fabrikasi. Proses fabrikasi dari organ tiruan melibatkan multidisiplin ilmu: teknik, kedokteran, biologi, kimia, fisika dsb. Sejak 2 dekade terakhir dikembangkan teknologi menanam sel ke bahan implan hasil printing 3 dimensi untuk mengarahkan diferensiasi sel.

Bab XVIII Mesenchymal Stem Cells from Extra-Embryonic Tissues for Tissue EngineeringRegeneration of the Peripheral Nerve disusun oleh Andrea Gärtner, Tiago Pereira, Raquel Gomes, Ana Lúcia Luís, Miguel Lacueva França, 
Stefano Geuna, Paulo Armada-da-Silva dan Ana Colette Maurício. Pada bab ini dijelaskan tentang kemajuan proses rekonstruksi jaringan tubuh seperti otak, sumsum tulang belakang dan otot jantung dengan sel induk. Sel induk adalah sel yang tidak terdiferensiasi, dengan proliferasi berkelanjutan tanpa henti dalam kapasitas diferensiasi in vitro dan multilineage. Kapasitas diferensiasi multiline in vitro ini telah menargetkan sel-sel ini dengan sangat penting untuk digunakan dalam terapi berbasis jaringan dan sel.

Bab XIX Hydroxyapatite (HA) Powder for Autovaccination Against Canine Non Hodgkin's Lymphoma disusun oleh Michel Simonet, Nicole Rouquet dan Patrick Frayssinet $\mathrm{Bab}$ ini menjelaskan tentang limfoma pada sistem hemolymphatic anjing. Limfoma dikenal dalam pengobatan manusia untuk merespons kemoterapi dan beberapa di antaranya bahkan dapat disembuhkan dengan protokol kemoterapi yang kompleks walaupun efek samping yang parah. Dijelaskan juga manfaat material HA untuk autovaksinasi terhadap limfoma anjing. Bab XX Dental Materials disusun oleh Junko Hieda, Mitsuo Niinomi, Masaaki Nakai and Ken Cho. Pada bab ini dijelaskan beberapa material gigi tiruan antara lain biomaterial metalik atau paduan gigi. Beberapa sifat yang diperlukan yakni memiliki ketahanan korosi yang tinggi, biokompatibilitas yang baik dan memiliki sifat mampu cor yang baik (castability). Dijelaskan juga dalam bab ini pembagian kelompok dari paduan gigi dan tren penggunaan paduan gigi berkarat rendah (paduan Ag dan Pd) karena harganya lebih murah. Bab XXI CeramicOn-Ceramic Joints: A Suitable Alternative Material Combination? disusun oleh Susan C. Scholes and Thomas J. Joyce. Pada bab ini dijelaskan tentang alternatif material untuk implan sambungan yaitu keramik-keramik. Hal ini sebagai solusi terhadap sambungan logam-keramik yang dalam beberapa kasus terjadi pelepasan partikel ion logam. Pelepasan partikel ion logam menyebabkan terganggunya proses penyembuhan pasien. Pada bab ini diberikan contoh kasus operasi tulang panggul (hip joint). Perkembangan ilmu biomaterial dalam beberapa tahun belakangan sangat pesat. Aplikasi biomaterial di bidang medis juga didukung dengan semakin canggihnya peralatan yang digunakan, mulai dari peralatan untuk karakterisasi material, rekayasa nanoteknologi hingga pengembangan teknologi organ tiruan manusia. Buku ini bisa menjadi salah satu referensi untuk mempelajari peran ilmu biomaterial di bidang medis. 